\title{
Stages of Development of Azerbaijani Romanticism
}

\author{
Aynur Sabitova $^{1}$ \\ ${ }^{1}$ Azerbaijan University of Languages, Azerbaijan \\ Correspondence: Aynur Sabitova, Azerbaijan University of Languages, Azerbaijan. E-mail: \\ sabitova-aynur@mail.ru
}

Received: November 29, 2012 Accepted: December 25, 2012 Online Published: January 28, 2013

doi:10.5539/ass.v9n2p295

URL: http://dx.doi.org/10.5539/ass.v9n2p295

\begin{abstract}
This article focuses on the most active period of romanticism in the Azerbaijan literature. The article lists the stages of development of Azerbaijani romanticism. Like any literary phenomenon the Azerbaijani romanticism has its own reference points: concrete time of origination, the stages of formation, development, giving in its positions and retirement from the literary scene. All these aspects have been analyzed.
\end{abstract}

Keywords: romanticism, critical realism, literature, literary scene

\section{Introduction}

Romanticism as literary school arose in Azerbaijan literature at the beginning of XX century whereas as a leading trend in the european and american literatures it gave way to a critical realism long ago. According to azerbaijani scientist Mir Jalal, "At the beginning of XX century there were favorable conditions for romantic literature, even romantic thought in Azerbaijan. The present period, i.e. the status quo of the country at that times didn't suit anybody. The means of salvation, a dream of happy future found quite a contradictory reflection in the literature. Some turned to the past, dreamt of the period of the reign of islamic caliphs, turkish sultans. That is why, going back to the past, history, the period of caliphates, they composed songs, issued an appeal, wrote dramas and tragedies." (Mir Jalal, 2004). At the same time it couldn't take up leading positions in the national literature as opposed to the european one of XIX century and along with critical realism became one of the main literary schools.

\section{The Epoch of Renaissance in the Azerbaijan Literature}

The age of romanticism in the Azerbaijani literature proved to be short. Its most striking repreasentatives came to literature in the years of the First Russian bourgeois revolution or immediately after it and starting from the middle of 1920 romanticism became displaced from the literary scene under the impact of a number of objective circumstances. To the moment of the change in socio-economic situation in the country (forced change of power and implanting Marxist-Leninist ideology as being the only one) some of the romantisists leaves this world (A. Sikhkhat, M. Khadi), some retreats from active literary activity (A. Shaig, A. Divanbeyoglu), some goes over to the realists (Jafar Jabbarly) and those who remained loyal to romanticism were killed (Javid). Thus, the most active and productive period of the Azerbaijani romanticism falls on the period between two russian revolutions, after which it is coming to an end, namely forcing out of literary reality.

At the beginning of XX century the positions of realistic literature in the Azerbaijan literature are being increased, i.e. educational realism predominating in XX century turns into critical one. And it is interesting that quite a number of educational ideas go over to the literature of critical realism. But emerging romanticism also comes out to be the successor of educational ideas. This allows us to assert that as opposed to quite a number of European literatures where romanticism emerged as anti-educational trend and critical realism is separated from enlightenment by the age of romanticism, in the Azerbaijan literature as well as quite a number of eastern literatures critical realism and romanticism carried on the educational traditions. In that sense critical realism and romanticism in the Azerbaijan literature advance and inculcated similar and close ideas by different in essence poetic means and methods of generalization.

Speaking of the peculiarity of the Azerbaijani romanticism, academician Mamed Jafar noted that "...its real essence in its idea", "general discontent, anxious, nervous and rebellious spirit were typical to all romanticists" (Mammad Jafar, 1963). This anxiety was caused by the status quo in the world, the deeds of the mankind, interrelations of the countries, as well as socio-political situation in the country, the status of the nation 
undergoing double oppression of the local landowners and manufacturers on the one hand and colonial authorities on the other.

The first half of XIX century in the western literatures passed under the banner of romanticism and the second under critical realism that displaced it. These two trends have existed in the Azerbaijan literature in parallel and the active phase of demand for them numbers less than a quarter of the century. The fact that such the most compound two literary phenomena formed and existed in parallel reaching the pinnacle of their development for such a short historical period, is a unique phenomenon in itself. It should be noted that some researchers calls this period the epoch of renaissance in the Azerbaijan literature (Mir Jalal, 2004).

About a century passed from that historical epoch. But the literary process of that period concerning romanticism hasn't yet received full and objective appraisal which was substantiated with tendentiousness and unacceptance of the positions of the soviet literary criticism unmatched to the ruling ideology. The creativity of the Azerbaijan romanticists in the soviet period was being studied as well. It is sufficient to remember the reputable works of such scientists as Mamed Jafar (Mammad Jafar, 1963), Veli Osmanly (Vali Osmanly, 1985), Masud Alioglu (Masud Alioglu, 1975), Yashar Garayev (Y. Garayev, 1982) etc. But they couldn’t recreate the true picture of development by the objective reasons. Although a certain work was done in this trend in the post-soviet period ("Azerbaijan romanticists" (Vali Osmanly, 2010) after V. Osmanly was issued in two volumes, which included portrait essay of the Azerbaijan romanticists, that for some reason or other was not included into one-volume publication of the same name; the book after Mir Jalal (Mir Jalal, 2004) that wasn't published in good time was issued now etc.), the white spots in the literary map of the epoch still remains to be.

The creative development of each representative of the Azerbaijani romanticism is studied separately and fully enough. But it is interesting that the way of the trend itself in the whole not only remains unstudied but its approximate borders were not yet outlined. There are certain stamps left as a result of the soviet ideological approach to literary phenomena. They include such notions as "progressive" and "conservative", "revolutionary" and "reactionary" romanticism. It is not considered to be true to subdivide the literary trend that existed about a quarter of the century and is represented by some great authors, into a number of groups and oppose them to each other on the basis of ideological and vital positions of the authors and more accurately optimistic or pessimistic view of life.

\section{Four Stages of Development of Azerbaijani Romanticism}

Like any literary phenomenon the Azerbaijani romanticism has its own reference point: concrete time of origination, the stages of formation, development, giving in its positions and retirement from the literary scene. All the researches of the Azerbaijani romanticism especially the researches of the creativity of its separate representatives agreed that this literary trend (some call it a school) arose in the years of the First Russian bourgeois revolution and reaction, and the peak of its development falls on the second decade of XX century and immediately after the establishment of the soviet government romanticism is leaving the literary scene. But the literary criticism still lacks the detailed summary analyses of the whole path of romanticism. The whole picture of the path of development of the Azerbaijani romanticism with relatively accurate separation of the certain periodization has not yet painted because of a number of objective and subjective reasons. Taking this into consideration we try to separate certain, scientifically substantiated periods in the history of development of the Azerbaijani romanticism.

Thus, the path of development of the Azerbaijani romanticism can be divided into the following stages:

1) The first stage is a stage of origination and formation that historically falls on the years of the First Russian bourgeois revolution and reaction that followed it. It is these years that A. Huseynzada creates the theoretical basis of this trend and A. Shaig, A. Sikhkhat, M. Khadi and H. Javid start their creative development. Romanticism goes through the stage of formation in that period and is mostly considered to be a trumpet of educational ideas. At the same time, the love for the Motherland in the first works of the romanticists sounds clearly and this is the manifestation of the national consciousness in Azerbaijan that was a colony of the Russian Empire. It is the motifs of the love for the Motherland and call for the enlightenment in the name of the future of the country that developed into the ideas of independence. The characteristic feature of romanticism of the first initial period is that it is generally represented with poetry that allows literature to quite rapidly respond to the events taking place in society.

2) The second stage covers almost the whole second decade of XX century. It can be called the period of mature romanticism as the main successes of the trend in the Azerbaijan literature falls on these years. It begins on the threshold of the World War I, covers on the whole the most complicated for the whole society period of wartime when it seemed that the world was destroyed. The romanticists sharply react to what is going on. M. Khadi 
participates as a volunteer in military operations reflecting all the seen horrors in his works. The characteristic feature of that period is that along with the poetry, romanticists turn to dramaturgy as well. There appearing the first plays of H. Javid and J. Jabbarly. If H. Javid turns to the remote past ("Sheikh Sanan") or mythical plot depicting the image of Iblis (Devil), then the young dramatist J. Jabbarly turns to the real reality but at the same time creates expressive romantic images. Responding to war and post-war "collapse of world" H. Javid creates the tragedy about the fight of the good against the evil on the theme of the Holy Bible and Guran ("Iblis") and J. Jabbarly creates the plays straight about the war and military operations (Y. Garayev, 1982).

3) The third stage, in our opinion, covers the 20s of XX century. This is the most complicated and ambiguous period: the pinnacle of the development of the Azerbaijani romanticism is left behind and romanticism as a literary trend is gradually excluded from the literary scene by force of objective and subjective reasons. By then such romanticists as Sikhkhat and Khadi left this world prematurely and shortly after it died S. Mansur. The establishment of the soviet government and persecution by the pro-government literature of those who didn't keep within the ideological "Procrustean bed", made many romanticists cease the active creativity and limited their access to the readers. On the other side, the young generation of literary men finding themselves under this ideological pressure, didn't completely come to the romanticism in spite of the domination of romantic principles in their works (M. Mushvig, S. Vurghun and others).

4) The fourth stage can only be singled out conditionally. Romanticism as a creative impulse is still in demand during this period but because of the careers of the militant socialist regime, the members of romanticism is firstly excluded from the literary scene and then for the most part killed physically. It should also be noted that at present in a number of post-soviet literature there is a tendency to review this approach.

\section{Conclusion}

On the basis of the carried investigation we come to the conclusion that all the researches of the Azerbaijani romanticism especially the researches of the creativity of its separate representatives agreed that this literary trend arose in the years of the First Russian bourgeois revolution and reaction, and the peak of its development falls on the second decade of XX century and immediately after the establishment of the soviet government romanticism is leaving the literary scene. But the literary criticism still lacks the detailed summary analyses of the whole path of romanticism. The whole picture of the path of development of the Azerbaijani romanticism with relatively accurate separation of the certain periodization has not yet painted because of a number of objective and subjective reasons. The analysis shows that romanticism as a creative impulse is still in demand.

\section{References}

Alioglu, M. (1975). The romanticism of Huseyn Javid. Baku: Azernashr.

Garayev, Y. (1982). Huseyn Javid. Baku: Elm.

Jafar, M. (1963). Romanticism in the Azerbaijani literature. Baku: USR SA.

Jalal, M. (2004). Literary schools in Azerbaijan (1905-1917). Baku: Ziya-Nurlan.

Osmanly, V. (1985). The romanticists of Azerbaijan. Baku: Yazichi.

Osmanly, V. (2010). The romanticists of Azerbaijan. Baku: Elm. 